\title{
Work Culture Analysis, Professionalism, Work Motivation In Improving The Quality Of Employment Education In Padang State University
}

\author{
Adelyn Alista Utami, Aldri Frinaldi \\ Public Administration Faculty Of Social Science Of Padang State University \\ Email: adelyn.alistautami@gmail.com
}

(Received: March 12-2020; revised: April 15-2020; published: June 31-2020)

\begin{abstract}
The big challenge facing bureaucracy is how they are able to carry out activities efficiently and effectively. Therefore, so far bureaucracy has been identified with convoluted performance, structure that is too large, full of collusion, corruption and nepotism, and there are no definite standards. Padang State University has currently carried out bureaucratic reform agendas from 2010 to 2014. Although not yet comprehensive and very well organized, the change agenda has been implemented and the results have been felt by employees and related stakeholders. However, the long road to bureaucratic reform continues, the challenges and problems of the bureaucracy have not been completely completed, requiring solutions and solutions to solve bureaucratic problems and create a professional bureaucracy. This study aims to determine the direct and indirect effects of work culture, professionalism and work motivation variables on the quality of work of educational staff at Padang State University. The method used is a quantitative method, with a survey approach. The study population was all education staff employees in the rector of Padang State University. The number of research samples was determined using the Slovin formula. The number of research samples as many as 160 people were determined by proportional stratified random sampling technique. The instrument used was a questionnaire that had been tested for validity and reliability. This study found that partially and simultan, work culture variables, professionalism and work motivation had a direct and indirect influence on the quality of work of educational staff at Padang State University.
\end{abstract}

Keywords: Work Culture; Professionalism; Work Motivation; Work Quality

\section{INTRODUCTION}

Bureaucracy is an important instrument in society, its presence cannot be avoided. Bureaucracy is a logical consequence of the hypothesis that the state has a goal which is to improve the welfare of its people through bureaucratic media, therefore the State must be directly involved.The state is actively involved in the social life of the community through bureaucracy and for that the state builds a good administrative system with the aim of serving the interests of its people because basically through the state bureaucracy directly responds to the needs and interests of the people themselves.

In accordance with the Regulation of the Minister of State PAN Number PER / 15 / M.PAN /7/2008 concerning General Guidelines for Bureaucratic Reform which was later refined with the Regulation of the Minister of State PAN and RB Number 20 of 2010 concerning Road Map of Bureaucratic Reform 2010-2014 and Presidential Regulation 
254|Jurnal Ilmiah Ilmu Administrasi Publik: Jurnal Pemikiran dan Penelitian Administrasi Publik Volume io Number 1, January - June 2020. Page 253-274

Number 81 In 2010 concerning the Grand Design of the 2010-2025 Bureaucracy Reform, all government agencies / institutions were required to carry out bureaucratic reforms to create good governance. One area of change in bureaucratic reform itself is the apparatus mentality which aims to create a positive work culture for serving, clean and accountable bureaucracies. With this, it is hoped that a clean and accountable, effective and efficient bureaucracy will be created and able to provide quality services.

The study of bureaucracy is a complex matter because it is related to various aspects, such as institutions, human resources, and the systems and procedures created and carried out by the bureaucracy, as well as aspects of bureaucratic reform called bureaucratic reform (Akib \& Ihsan, 2017; Mathwich \& Pavao-Zuckerman, 2018; Meier \& Krause, 2003; Wihantoro et al., 2015; Yusriadi et al., 2019). In this context, the state builds an administrative system that aims to serve the interests of its people, which is called the bureaucracy.

The big challenge facing bureaucracy is how they are able to carry out activities efficiently and effectively (Jain, 2004; Osborne \& Plastrik, 1997; Provan et al., 2017; Ripley \& Franklin, 1968; Weber, 1946, 1947). Therefore, so far bureaucracy has been identified with convoluted performance, structure that is too large, full of collusion, corruption and nepotism, and there are no definite standards. A number of bureaucratic problems become very significant obstacles in the context of the realization of bureaucratic reform. One of them is the existence of mindset (mind-set) and work culture (culture-set) that have not fully supported professional bureaucracy and not optimal human resource management practices in increasing professionalism. For this reason, Indonesia's bureaucracy is very far from what is called good governance.

When discussing bureaucracy, it will certainly relate to employees who carry out the bureaucracy based on hierarchy and rank levels, clearly underlining the main role of bureaucratic actors or actors, namely the government apparatus. Thus, the basic foundation of the whole bureaucracy must begin with an improvement in the Human Resource management of the apparatus. The Human Resource management of this apparatus is an urgent need to be carried out in order to obtain apparatus with integrity, competence, professionalism, high performance and prosperity in supporting the achievement of good bureaucracy management. The Human Resource Management of this apparatus is an urgent need to be carried out in order to obtain apparatus with integrity, competence, professionalism, high performance and prosperity in supporting the achievement of good bureaucracy management.

The quality of employee work is a concern of the world today. This happens as a consequence of the demands of society for the need for excellent service or high quality services. Quality is inseparable from the standard, because the quality of employee work can be measured according to standards. Through the quality of apparatus work, it is expected to be able to show a real professional contribution in improving the quality of public services in general at the organization where it works and the eventual impact will lead to the quality of life and welfare of the community.

(Robbins, 1994) states that motivation is a process that explains the intensity, direction and perseverance of individuals to achieve their desired goals. Whereas (Pareek, 1974) 
defines motivation as a process of (a) arising or initiating initiatives, (b) maintaining an ongoing activity, (c) channeling activities into a particular course.

However, the commitment and support of top leaders and other stakeholders remains the main key. Meeting the same perception between the two components in determining goals and objectives, is the main capital to improve performance in an organization. Determining the level of achievement through work quality indicators will touch directly the factors that show objective indications of the implementation of functions and tasks of the apparatus, and can assess the extent to which functions and tasks performed have met the specified standards (Farida, 2017; Nawir et al., 2018; Niswaty et al., 2019).

According to (Clarke, 1983), the final goal of human resource management efforts is to create a condition where employees can achieve high productivity, employees are able to stay in the organization for a long time, low levels of absenteeism, achievement of satisfaction of service users, and finally employees feel satisfied in carrying out their duties in the organization. If this is created, it can be said that the bureaucratic reforms carried out in improving performance are affective or successful.

Work culture as a form of values owned by employees in carrying out their work also has an influence on the quality of work. Because, if the work culture of the organization is right for the condition of the company, employees and the work environment, then the quality of work in a company will be good. In addition, good employee professionalism will provide good performance, because employees work according to their knowledge and skills. In addition, to provide good quality motivation is needed at work, so that with the motivation at work, will provide good quality work.

Padang State University has currently carried out bureaucratic reform agendas from 2010 to 2019. Although not yet comprehensive and very well organized, the change agenda has been implemented and the results have begun to be felt by employees and relevant stakeholders. However, the long road to bureaucratic reform continues, the challenges and problems of the bureaucracy have not been completely completed, requiring solutions and solutions to solve bureaucratic problems and create a professional bureaucracy.

Padang State University is currently still a Public Service Agency, which has a work culture orientation, values and work ethics that are different from the previous conditions when it was still a Work Unit. Before 2015, Padang State University had not yet clearly established a work culture that would be internalized by the entire Padang State University. Since 2015 Padang State University has been committed to the changing work culture that is "Professional, Competent, Committed, Empathy and Devotion".

With the established work culture it is expected that the academics of Padang StateUniversity have high integrity in carrying out work. In fact there are still academics who do not understand well the values of work culture that have been set. As a result, work attitudes and behavior are not in accordance with the values of the work culture. For example there are still some educators and educational staff who work not according to Standard Operating Procedures. This is still happening because of the consistently low supervision in implementing the Standard Operating Procedures consistently.

In addition, employees at Padang State University differ in their needs when they are satker. Padang State University is of inadequate quality, there are still gaps between qualifications and competencies and organizational needs, inaccurate employee placement in 
256|Jurnal Ilmiah Ilmu Administrasi Publik: Jurnal Pemikiran dan Penelitian Administrasi Publik Volume io Number 1, January - June 2020. Page 253-274

accordance with their competencies, and ineffective staffing management systems based on performance. Other problems are related to staffing data / information, namely the lack of awareness and participation of work units in managing staffing data so that it affects the level of accuracy, updated, integrated, and integrated use. Meanwhile, Padang State University does not yet have a training that is used as a place for employee training and education.

Since 2015, Padang State University has no longer recruited Civil Servant Candidates for the formation of education personnel, because no allocation of civil service staffing is given by the Ministry of Administrative Reform and Bureaucratic Reform. So that more recruitment of education personnel is done with the employment contract system. The number of education staff at Padang State University at present based on education is as follows:

Table 1

Number of Education Personnel as at 31 January 2019

\begin{tabular}{|l|c|c|c|c|c|c|}
\hline Education / Status & $\begin{array}{c}\text { <Senior } \\
\text { High } \\
\text { School }\end{array}$ & $\begin{array}{c}\text { Senior } \\
\text { High } \\
\text { School }\end{array}$ & D2/D3 & S1 & S2 & Amount \\
\hline Civil Servants & 7 & 139 & 54 & 145 & 33 & 378 \\
\hline Non Civil Servants & 0 & 83 & 59 & 176 & 18 & 336 \\
\hline
\end{tabular}

The education staff above are the number of employees who provide services and carry out technical activities at Padang State University. In addition, there are still many High School graduates rather than the number of Diploma graduates on this campus, which will certainly have an influence on the quality of work of the educational staff. Meanwhile, Padang State University there is no special education and training unit used as a center for employee competency development.

\section{METHOD}

This research uses quantitative research, the method used to test certain theories by examining the relationships between variables. The form of problems in this quantitative research is associative. Associative problems are research problems relating to the relationship between two or more research variables (Creswell \& Poth, 2018). The strategy used in this study is a survey strategy. Survey strategies are strategies that describe quantitatively the tendencies, attitudes or opinions of a population (Creswell \& Creswell, 2017).

This research was conducted at the Central Campus of Padangyang State University with its address at Jl. Prof. Dr Hamka, Kelurahan Air Tawar Barat, Padang Utara Subdistrict, Padang City, which is focused on employees who work at the Padang State University 
rector. The Rectorate is the locus, because the center of all activities in the Padang State University campus is in this sector.

\section{RESULT AND DISCUSSION General Descriptions of Research Objects}

This section will explain the general description of the object of research based on gender, age, employment status, salary and ethnicity.

\section{Characteristics of Respondents by Gender}

The characteristics of respondents in this study based on gender, can be seen in the following table:

Table 2

Characteristics of Respondents by Gender

\begin{tabular}{clcccc}
\hline \multicolumn{5}{c}{} & \multicolumn{4}{c}{ Gender } \\
& Frequency & Percent & $\begin{array}{c}\text { Valid } \\
\text { Percent }\end{array}$ & Cumulative Percent \\
\hline \multirow{3}{*}{ Valid } & Male & 79 & 49.4 & 49.4 & 49.4 \\
\cline { 2 - 6 } & Female & 81 & 50.6 & 50.6 & 100.0 \\
\cline { 2 - 6 } & Total & 160 & 100.0 & 100.0 & \\
\hline
\end{tabular}

Based on the data above, it can be seen that the number of male and female respondents in this study is almost balanced, with a percentage of men equal to $49.4 \%$, while the percentage of respondents having female is $50.6 \%$. Based on the data above, the characteristics of respondents according to sex in this study are well distributed.

\section{Characteristics of Respondents by Age}

The characteristics of respondents in this study based on age can be seen in the following table:

Table 3

Characteristics of Respondents by Age

\begin{tabular}{cccccc}
\hline & \multicolumn{5}{c}{ Age } \\
\hline & Frequency & Percent & Valid Percent & $\begin{array}{c}\text { Cumulative } \\
\text { Percent }\end{array}$ \\
\hline \multirow{4}{*}{ Valid } & Under 20 years & 1 & .6 & .6 & .6 \\
\cline { 2 - 6 } & $21-30$ years & 50 & 31.3 & 31.3 & 31.9 \\
\cline { 2 - 6 } & $31-40$ years & 59 & 36.9 & 36.9 & 68.8 \\
\cline { 2 - 6 } & $41-50$ years & 22 & 13.8 & 13.8 & 82.5 \\
\cline { 2 - 6 } & Over 50 years & 28 & 17.5 & 17.5 & 100.0 \\
\hline
\end{tabular}


258|Jurnal Ilmiah Ilmu Administrasi Publik: Jurnal Pemikiran dan Penelitian Administrasi Publik Volume io Number 1, January - June 2020. Page 253-274

Total $160 \quad 100.0 \quad 100.0$

Based on the data above, it can be seen that respondents who are based on age characteristics are scattered at each level. The highest number of respondents was in the age range of 31-40 years with a percentage of $36.9 \%$. Whereas the lowest percentage is respondents under 20 years with a total of 1 person and a percentage of $0.6 \%$. Based on the data above, the characteristics of respondents according to age in this study are well distributed.

\section{Characteristics of Respondents Based on Employee Status}

The characteristics of research respondents based on employee status, can be seen in the table below:

Table 4

Characteristics of Respondents Based on Employee Status

\begin{tabular}{clcccc}
\hline \multicolumn{5}{c}{ Employment Status } \\
\hline \multirow{3}{*}{ Valid } & Frequency & Percent & Valid Percent & Cumulative Percent \\
\cline { 2 - 6 } & Civil Servants & 84 & 52.5 & 52.5 & 52.5 \\
\cline { 2 - 6 } & $\begin{array}{l}\text { Non Civil } \\
\text { Servants }\end{array}$ & 76 & 47.5 & 47.5 & 100.0 \\
\cline { 2 - 6 } & Total & 160 & 100.0 & 100.0 & \\
\hline
\end{tabular}

Based on the data above, it can be seen that there are two employee status distributions, with more PNS employees than Non PNS employees. The percentage of civil servants is $52.5 \%$. Whereas for Non PNS is $47.5 \%$. Based on available data, the research sampling with strata of PNS and Non PNS in this study was distributed proportionally.

\section{Characteristics of Respondents Based on Large Salary}

The characteristics of respondents based on the salary scale of respondents, can be seen in the table below:

Table 5

Characteristics of Respondents Based on Large Salary

\begin{tabular}{lllccc}
\hline \multicolumn{5}{c}{ Salary Scale } \\
\hline & Frequency & Percent & $\begin{array}{c}\text { Valid } \\
\text { Percent }\end{array}$ & $\begin{array}{c}\text { Cumulative } \\
\text { Percent }\end{array}$ \\
\hline \multirow{4}{*}{ Valid } & Under Rp.2.200.000 & 1 & .6 & .6 & .6 \\
\cline { 2 - 6 } & Rp.2.200.001 - RP.3.000.000 & 86 & 53.8 & 53.8 & 54.4 \\
\cline { 2 - 6 } & Rp.3.000.001 - Rp.3.800.000 & 39 & 24.4 & 24.4 & 78.8 \\
\cline { 2 - 6 } & Rp.3.800.001 - Rp.4.600.000 & 16 & 10.0 & 10.0 & 88.8 \\
\cline { 2 - 6 } & Over RP.4.600.000 & 18 & 11.3 & 11.3 & 100.0 \\
\hline
\end{tabular}




$100.0 \quad 100.0$

Based on the data above, the most respondents in this study were respondents who had a salary ranging from Rp. 2,200,001 - Rp. 3,000,000 with a percentage of 53.8\%. Whereas the respondents who were the least based on the amount of salary were salaries below Rp. $2,200,000$ with a percentage of $0.6 \%$. Based on the data above, then the characteristics of respondents according to the amount of salary in this study are well distributed.

\section{Characteristics of Respondents Based on Ethnicity}

The ethnic characteristics of the respondents in this study can be seen in the following table:

Table 6

Characteristics of Respondents Based on Ethnicity

\begin{tabular}{llcccc}
\hline & \multicolumn{5}{c}{ Ethnic } \\
\hline \multirow{4}{*}{ Valid } & Frequency & Percent & Valid Percent & Cumulative Percent \\
\cline { 2 - 6 } & Minang & 148 & 92.5 & 92.5 & 92.5 \\
\cline { 2 - 6 } & Mandailing & 1 & .6 & .6 & 93.1 \\
\cline { 2 - 6 } & Jawa & 9 & 5.6 & 5.6 & 98.8 \\
\cline { 2 - 6 } & Other & 2 & 1.3 & 1.3 & 100.0 \\
\hline
\end{tabular}

In this table, it can be seen if it is based on ethnicity, then most respondents of this study are ethnic Minang with a percentage of $92.5 \%$ or as many as 148 . While the least ethnic respondents were mandailing ethnic respondents with a percentage of $0.6 \%$ or with the number of respondents as much as one person.

\section{Variable Description}

The average value of the variables in this research are as follows:

Table 7

Normality Test $\mathrm{X} 1$ and $\mathrm{X} 2$ against $\mathrm{X3}$

\begin{tabular}{|c|c|c|c|c|c|c|c|}
\hline \multirow{3}{*}{ Variable } & \multirow{3}{*}{ Mean } & \multicolumn{4}{|c|}{$\begin{array}{c}\text { Characteristics of Respondent } \\
\text { Mean }\end{array}$} & \multirow{2}{*}{\multicolumn{2}{|c|}{$\begin{array}{c}\text { Total } \\
\text { Respondent } \\
\text { Mean }\end{array}$}} \\
\hline & & \multicolumn{2}{|c|}{ High } & \multicolumn{2}{|c|}{ Low } & & \\
\hline & & $\mathrm{F}$ & $\%$ & $\mathrm{~F}$ & $\%$ & $\mathrm{~F}$ & $\%$ \\
\hline Work Culture & 3.89 & 80 & 50 & 80 & 50 & 160 & 100 \\
\hline Professionalism & 3.86 & 73 & 45.63 & 87 & 54.37 & 160 & 100 \\
\hline Work motivation & 4.20 & 76 & 47.5 & 84 & 52.5 & 160 & 100 \\
\hline Work quality & 3.88 & 90 & 56.25 & 70 & 43,75 & 160 & 100 \\
\hline
\end{tabular}


260 Jurnal Ilmiah Ilmu Administrasi Publik: Jurnal Pemikiran dan Penelitian Administrasi Publik Volume 10 Number 1, January - June 2020. Page 253-274

Based on the above table, it can be seen that for the average or mean values among the high pling variables is work motivation. Whereas the lowest average is the professionalism variable. The characteristics of the average respondent who has a high average answer is the variable quality of work, with the highest average frequency of 90 , with a percentage of $56.25 \%$. As for the mean characteristics of respondents who have an average low answer is the work culture variable with a frequency of 80 and a percentage of $50 \%$.

The above data also states that based on the four variables studied by the researchers, the work motivation towards employees has been done well by the institution. As for professionalism, employees have a good average, but when compared with other variables in this study, it is still at the bottom.

\section{Effect of Work Culture (X1) and Professionalism (X2) on Work Motivation (X3)}

Based on the classic assumption test that has been done using SPSS version 20.0, the normality test results are as follows:

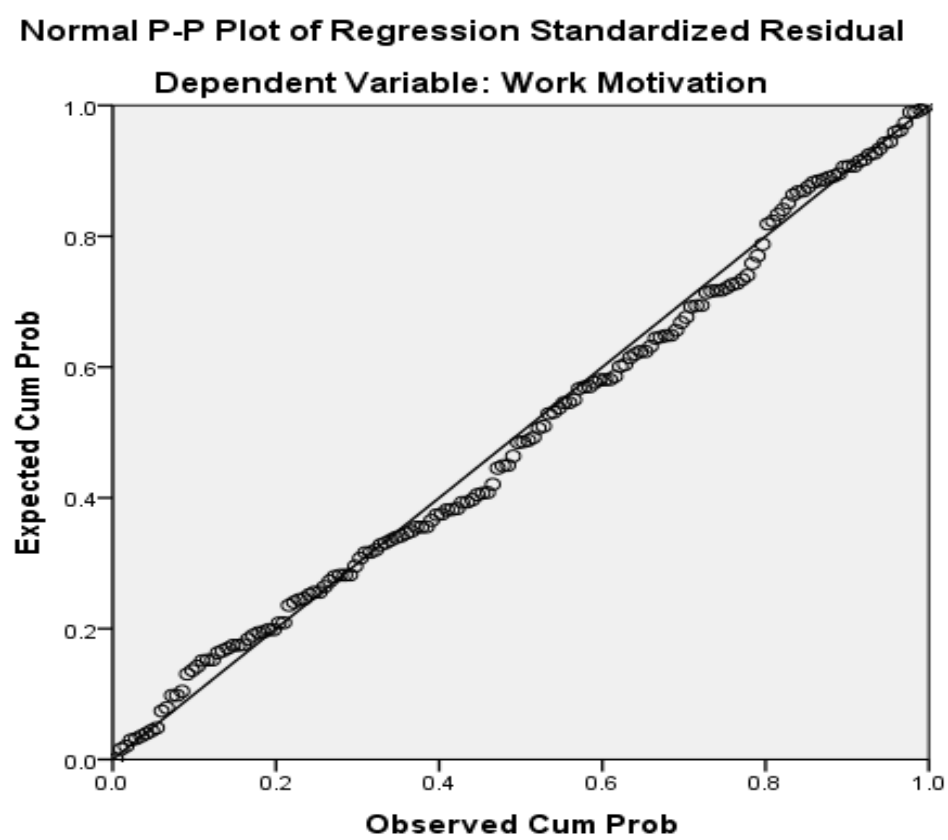

Figure 1

Normality Test X1 and X2 against X3

Based on the picture above, it can be seen that the data is normally distributed, which is indicated by the presence of dots along the lines. This states that the data in this study are eligible for a regression test, because the data do not have any disruption in their distribution.

a) Multicollinearity Test 
The results of the multicollinearity test in this first model can be seen in the table in the Table 8 following table:

Multicollinearity Test X1 and X2 against X3

\begin{tabular}{|c|c|c|c|c|c|c|c|c|}
\hline & 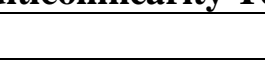 & & & Coefficients $^{\mathrm{a}}$ & & & & \\
\hline & & $\begin{array}{r}\text { Unstand } \\
\text { Coeffi }\end{array}$ & $\begin{array}{l}\text { rdized } \\
\text { ents }\end{array}$ & $\begin{array}{l}\text { Standardized } \\
\text { Coefficients }\end{array}$ & & & $\begin{array}{r}\text { Colline } \\
\text { Statist }\end{array}$ & \\
\hline & Model & B & $\begin{array}{l}\text { Std. } \\
\text { Error }\end{array}$ & Beta & $\mathrm{T}$ & Sig. & Tolerance & VIF \\
\hline & (Constant) & 18.803 & 5.185 & & 3.626 & .000 & & \\
\hline 1 & Work Culture & .563 & .098 & .366 & 5.746 & .000 & 883 & 1.132 \\
\hline & Professionalism & .694 & .100 & .441 & 6.924 & .000 & 883 & 1.132 \\
\hline & & a. DeI & ident & Variable: Wor & Motiv & & & \\
\hline
\end{tabular}

In the table, it can be seen that the VIF value is smaller than 10 . In addition, the magnitude of the tolerance value is also greater than 0.10 . This states that the research data, there is no multicollinearity problem among the research variables. In other words, between variables $\mathrm{X} 1, \mathrm{X} 2$ and $\mathrm{X} 3$ there is no perfect correlation.

b) Heteroscedasticity Test

The results of the heteroscedasticity test of this study can be seen in the following figure:

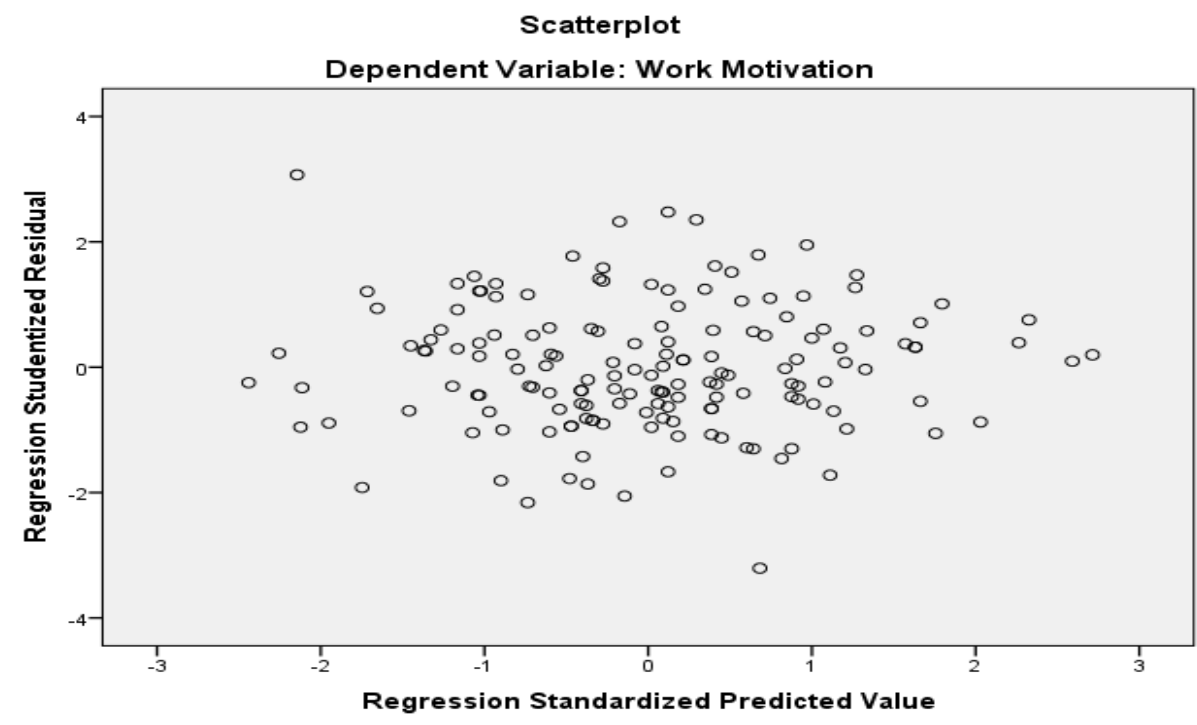

Figure 2

Heteroscedasticity Test X1 and X2 against X3

Based on the figure, the points represent the data that is scattered above the zero on the $\mathrm{Y}$ axis. It also shows that the points do not make a particular pattern. That way, it can be 
262 Jurnal Ilmiah Ilmu Administrasi Publik: Jurnal Pemikiran dan Penelitian Administrasi Publik Volume 10 Number 1, January - June 2020. Page 253-274

stated that there is no heteroscedasticity problem. In other words, the X1 and X2 against X3 tests do not occur data deviation.

8. Effect of Work Culture (X1), Professionalism (X2) and Work Motivation (X3) on Work Quality (Y).

a) Test Normality

The normality test results in the second stage can be seen in the picture as follows:

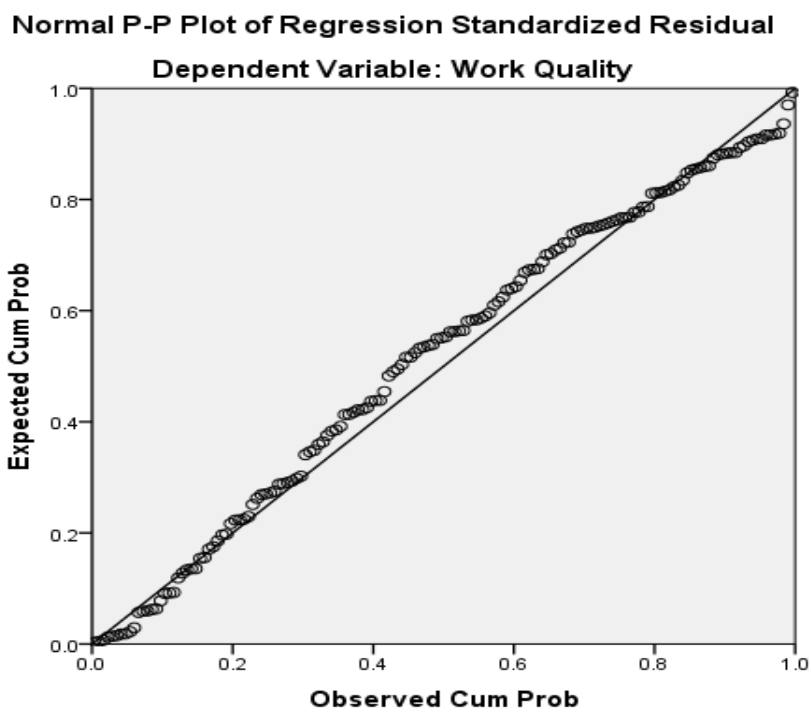

Figure 3

Normality Test $\mathrm{X} 1, \mathrm{X} 2$ and $\mathrm{X} 3$ against $\mathrm{Y}$

Based on the data above, it can be seen that the dot points are spread along the diagonal line. This states that the research data is spread or well distributed. Therefore, a regression test can be performed.

b) Multicollinearity Test

The multicollinearity test results in this study can be seen in the table below:

Table 9

Multicollinearity Test Variables X1, X2 and X3 against Y

\begin{tabular}{|c|c|c|c|c|c|c|c|c|}
\hline \multicolumn{9}{|c|}{ Coefficients $^{\mathrm{a}}$} \\
\hline & \multirow[t]{2}{*}{ Model } & \multicolumn{2}{|c|}{$\begin{array}{l}\text { Unstandardized } \\
\text { Coefficients }\end{array}$} & \multirow{2}{*}{$\begin{array}{c}\text { Standardized } \\
\text { Coefficients } \\
\text { Beta }\end{array}$} & \multirow[t]{2}{*}{$\mathrm{t}$} & \multirow[t]{2}{*}{ Sig. } & \multicolumn{2}{|c|}{$\begin{array}{l}\text { Collinearity } \\
\text { Statistics }\end{array}$} \\
\hline & & B & Std. Error & & & & Tolerance & VIF \\
\hline \multirow{3}{*}{1} & (Constant) & 18.803 & 5.185 & & 3.626 & .000 & & \\
\hline & Work Culture & .563 & .098 & .366 & 5.746 & .000 & .883 & 1.132 \\
\hline & Professionalism & .694 & .100 & .441 & 6.924 & .000 & .883 & 1.132 \\
\hline
\end{tabular}


a. Dependent Variable: Work Motivation

Based on the data above, it can be seen that the Tolerance value has a value greater than 0.10. Whereas the VIF value is smaller than 10. With this, it can be stated that in this study there were no multicollinearity problems.It also states that there is no perfect correlation between the research variables.

c) Heteroscedasticity Test

The heteroscedasticity test results in this study can be seen in the image below:

Scatterplot

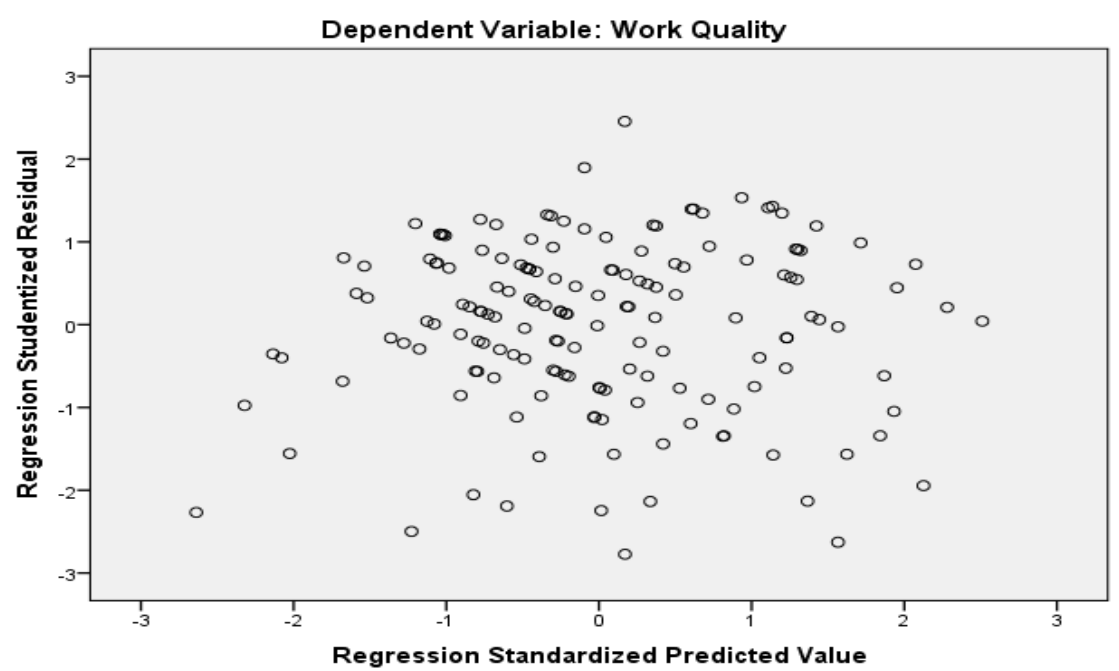

Figure 4

Heteroscedasticity Test Variables X1, X2 and X3 against $Y$

Based on the data above, it can be seen that the researchers' data which are represented by dots, are located above and below zero on the $\mathrm{Y}$ axis. The point also does not form a certain pattern. This matter can be interpreted that in this research data there is no heteroscedasticity problem in this research variable. In other words, there are no deviations that occur between the research variables.

d) Hypothesis Test on $\mathrm{T}$

$\mathrm{T}$ test is a test conducted to see the effect of independent variables on the dependent variable partially. The $\mathrm{T}$ Test conducted in this study can be seen in accordance with the research hypothesis.

i. First Hypothesis

The first hypothesis aims to examine the presence or absence of the influence of work culture variables on work quality. The partial test results can be seen below. 
264 Jurnal Ilmiah Ilmu Administrasi Publik: Jurnal Pemikiran dan Penelitian Administrasi Publik Volume 1o Number 1, January - June 2020. Page 253-274

Table 10

Test the Effect of X1 on Y

\begin{tabular}{ccccccc}
\hline \multicolumn{7}{c}{ Coefficients $^{\mathbf{a}}$} \\
\hline \multirow{2}{*}{ Model } & \multicolumn{2}{c}{ Unstandardized Coefficients } & \multicolumn{2}{c}{$\begin{array}{c}\text { Standardized } \\
\text { Coefficients }\end{array}$} & \multirow{2}{*}{$\mathrm{t}$} & Sig. \\
\cline { 2 - 5 } & \multicolumn{2}{c}{$\mathrm{B}$} & Std. Error & Beta & & \\
\hline \multirow{2}{*}{1} & 20.595 & 2.326 & & 8.856 & .000 \\
\hline & $\begin{array}{c}\text { (Constant) } \\
\text { Work } \\
\text { Culture }\end{array}$ & .269 & .060 & .339 & 4.524 & .000 \\
\hline
\end{tabular}

a. Dependent Variable: Work Quality

Based on the data above, it can be seen that partially there is an influence of work culture on work quality with a significance of 0.00 . This states that the influence of X1 on Y is $100 \%$ reliable. As for the beta value of the results of this partial test is 0.339 . It also states that $\mathrm{HO}$ was rejected and Ha was accepted.

ii. Second Hypothesis

The second hypothesis is to examine the effect of professionalism on work quality. The results of the test data can be seen below:

Table 11

Test Effects of X2 on Y

\begin{tabular}{|c|c|c|c|c|c|c|}
\hline \multicolumn{7}{|c|}{ Coefficients $^{\mathrm{a}}$} \\
\hline & \multirow[t]{2}{*}{ Model } & $\begin{array}{r}\text { Unst } \\
\mathrm{Co}\end{array}$ & $\begin{array}{l}\text { ardized } \\
\text { cients }\end{array}$ & $\begin{array}{l}\text { Standardized } \\
\text { Coefficients }\end{array}$ & \multirow[t]{2}{*}{$\mathrm{t}$} & \multirow[t]{2}{*}{ Sig. } \\
\hline & & $\mathrm{B}$ & Std. Error & Beta & & \\
\hline \multirow{2}{*}{1} & (Constant) & 12.016 & 2.878 & & 4.175 & .000 \\
\hline & Professionalism & .379 & .057 & 467 & 6.637 & .000 \\
\hline
\end{tabular}

Based on the data above, it can be seen that the significance of the t test results is 0.00 . This can be interpreted that there is a positive influence of variable $\mathrm{X} 2$ on $\mathrm{Y}$ whose influence can be trusted $100 \%$. The beta value produced in this $t$ test was 0.467 .

iii. Third Hypothesis

This third hypothesis is to prove that there is an influence of work motivation variable (X3) on the quality of work (Y) of teaching staff at Padang State University. The results are as follows: 
Table 12

Test the Effect of X3 on Y

\begin{tabular}{|c|c|c|c|c|c|c|}
\hline \multicolumn{7}{|c|}{ Coefficients $^{\mathrm{a}}$} \\
\hline & \multirow[t]{2}{*}{ Model } & \multicolumn{2}{|c|}{ Unstandardized Coefficients } & $\begin{array}{l}\text { Standardized } \\
\text { Coefficients }\end{array}$ & \multirow[t]{2}{*}{$\mathrm{T}$} & \multirow[t]{2}{*}{ Sig. } \\
\hline & & $\mathrm{B}$ & Std. Error & Beta & & \\
\hline \multirow{2}{*}{1} & (Constant) & 9.789 & 2.607 & & 3.754 & .000 \\
\hline & Work Motivation & .282 & .034 & .546 & 8.186 & .000 \\
\hline
\end{tabular}

Based on the data above, it can be seen that an alternative hypothesis is accepted. In other words that there is a positive influence on the $\mathrm{X} 3$ variable for $\mathrm{Y}$. The results can be seen from the significance of less than 0.05 , which is equal to 0.00 . It can also be interpreted that the influence that is based on the results of this test can be trusted $100 \%$ truth. The large beta value is 0.546 .

iv. Fourth Hypothesis

The fourth hypothesis in this study is to look at the influence of work culture (X1) on work motivation (X3). The results of the $t$ test are as follows:

Table 13

Test Effects of X1 against X3

\begin{tabular}{ccccccc}
\hline \multicolumn{7}{c}{ Coefficients $^{\mathbf{a}}$} \\
\hline \multirow{2}{*}{ Model } & \multicolumn{2}{c}{ Unstandardized Coefficients } & $\begin{array}{l}\text { Standardized } \\
\text { Coefficients }\end{array}$ & \multirow{2}{*}{ S } & Sig. \\
\cline { 2 - 7 } & \multicolumn{1}{c}{$\mathrm{B}$} & Std. Error & Beta & & \\
\hline \multirow{2}{*}{1} & (Constant) & 44.630 & 4.103 & & 10.878 & .000 \\
\cline { 2 - 7 } & Work Culture & .795 & .105 & .516 & 7.576 & .000 \\
\hline \multicolumn{7}{c}{ a. Dependent Variable: Work Motivation } \\
\hline
\end{tabular}

Based on these data, it can be seen that the significance of this study is 0.00 whose value is small than the standard error value of 0.05 . This means that there is a positive influence of $\mathrm{X} 1$ on $\mathrm{X} 3$ that can be trusted $100 \%$ truth. The beta value of this research is 0.516 .

v. Fifth Hypothesis

This fifth hypothesis is to find out the influence of the variable professionalism (X2) on work motivation (X3). The results of the t test can be seen in the following table: 
266 Jurnal Ilmiah Ilmu Administrasi Publik: Jurnal Pemikiran dan Penelitian Administrasi Publik

Volume 10 Number 1, January - June 2020. Page 253-274

Table 14

Test the Effect of X2 on X3

\begin{tabular}{ccccccc}
\hline \multicolumn{7}{c}{ Coefficients $^{\mathrm{a}}$} \\
\hline \multirow{2}{*}{ Model } & \multicolumn{2}{c}{ Unstandardized Coefficients } & $\begin{array}{c}\text { Standardized } \\
\text { Coefficients }\end{array}$ & \multirow{2}{*}{$\mathrm{T}$} & Sig. \\
\cline { 2 - 6 } & $\mathrm{B}$ & Std. Error & Beta & & \\
\hline \multirow{2}{*}{1} & (Constant) & 30.833 & 5.203 & & 5.927 & .000 \\
\cline { 2 - 6 } & Professionalism & .891 & .103 & .566 & 8.621 & .000 \\
\hline
\end{tabular}

a. Dependent Variable: Work Motivation

Based on the data above, it can be seen that the significance value of 0.00 is smaller than 0.05 . This states that there is an influence of $\mathrm{X} 2$ on $\mathrm{X} 3$, which is a positive influence and can be trusted $100 \%$ truth. Then, for the beta value in this study amounted to 0.566 .

e) Hypothesis Test on F

The $\mathrm{F}$ test is a test conducted using multiple regression analysis. This test is also commonly called the simultaneous variable test, which involves more than 2 variables. The $\mathrm{F}$ test is adjusted to the research hypothesis. The hypothesis can be seen as follows.

vi. The Sixth Hypothesis

This sixth hypothesis is to look at the influence of work culture (X1) and professionalism (X2) on work motivation (X3) of education staff at Padang State University. The results are as follows:

Table 16

Contribution of X1 and X2 to X3

\begin{tabular}{lcccc}
\hline \multicolumn{5}{c}{ Model Summary $^{\mathbf{b}}$} \\
\hline Model & $\mathrm{R}$ & R Square & Adjusted R Square & Std. Error of the Estimate \\
& & & .431 & 4.843 \\
\hline 1 & $.662^{\mathrm{a}}$ & .438 & a. Predictors: (Constant), Professionalism, Work Culture & \\
\hline \multicolumn{5}{c}{ b. Dependent Variable: Work Motivation } \\
\hline
\end{tabular}

Based on the results of data processing above, it can be seen that for the magnitude of the contribution of $\mathrm{X} 1$ and $\mathrm{X} 2$ to $\mathrm{X} 3$ can be seen based on the adjusted $\mathrm{R}$ square value of 0.431 which means that work culture and professionalism affect work motivation by $43.1 \%$.

vii. Seventh Hypothesis

This hypothesis examines the influence of work culture variables and professionalism simultaneously on the quality of work. The results of the $\mathrm{F}$ test carried out can be seen as follows: 
Table 17

Test Effects of X1 and X2 on Y

\begin{tabular}{ccccccc}
\hline \multicolumn{7}{c}{ ANOVA $^{\mathbf{a}}$} \\
\hline & Model & Sum of Squares & Df & Mean Square & F & Sig. \\
\hline \multirow{2}{*}{1} & Regression & 443.783 & 2 & 221.892 & 26.783 & $.000^{b}$ \\
\cline { 2 - 7 } & Residual & 1300.711 & 157 & 8.285 & & \\
\cline { 2 - 7 } & Total & 1744.494 & 159 & & & \\
\hline
\end{tabular}

a. Dependent Variable: Work Quality

b. Predictors: (Constant), Professionalism, Work Culture

Based on the data above, it can be seen for a small significance value of 0.05 . This states that there is a positive influence of $\mathrm{X} 1$ and $\mathrm{X} 2$ simultaneously on $\mathrm{Y}$ whose truth can be trusted $100 \%$. The contribution of independent variables to the dependent variable can be seen in the table below.

Table 18

Contribution values of $\mathrm{X} 1$ and $\mathrm{X} 2$ to $\mathrm{Y}$

\begin{tabular}{ccccc}
\hline \multicolumn{5}{c}{ Model Summary } \\
\hline Model & $\mathrm{R}$ & R Square & Adjusted R Square & Std. Error of the Estimate \\
\hline 1 & $.504^{\mathrm{a}}$ & .254 & .245 & 2.878 \\
\hline
\end{tabular}

a. Predictors: (Constant), Professionalism, Work Culture

Based on the data above, the effect of $\mathrm{X} 1$ and $\mathrm{X} 2$ on $\mathrm{Y}$ is based on the adjusted $\mathrm{R}$ square value which has a value of 0.245 . This states that the magnitude of the contribution of work culture and professionalism variables to the work quality variable simultaneously is $25.5 \%$.

viii. The Eighth Hypothesis

In this eight hypothesis tested the effect of work culture variables (x1), professionalism (X2) and work motivation (X3) on work quality (Y) simultaneously. This can be seen in the table below. 
268 Jurnal Ilmiah Ilmu Administrasi Publik: Jurnal Pemikiran dan Penelitian Administrasi Publik Volume 10 Number 1, January - June 2020. Page 253-274

Table 19

Test Effects of X1, X2 and X3 on Y

\begin{tabular}{|c|c|c|c|c|c|}
\hline \multicolumn{6}{|c|}{ ANOVA $^{a}$} \\
\hline Model & Sum of Squares & Df & Mean Square & $\mathrm{F}$ & Sig. \\
\hline Regression & 588.691 & 3 & 196.230 & 26.485 & $.000^{\mathrm{b}}$ \\
\hline 1 Residual & 1155.803 & 156 & 7.409 & & \\
\hline Total & 1744.494 & 159 & & & \\
\hline \multicolumn{6}{|c|}{ a. Dependent Variable: Work Quality } \\
\hline \multicolumn{6}{|c|}{ b. Predictors: (Constant), Work Motivation, Work Culture, Professionalism } \\
\hline
\end{tabular}

Based on the data above, it can be seen that the significance value is small than 0.05 , which is equal to 0.00 . . This can be interpreted that there is an effect of variables $\mathrm{X} 1, \mathrm{X} 2$ and X3 on Y simultaneously, and that influence can be trusted $100 \%$. The amount of influence can be seen in the table below.

Table 20

Contribution values of $\mathrm{X} 1, \mathrm{X} 2$ and $\mathrm{X3}$ to $\mathrm{Y}$

\begin{tabular}{ccccc}
\hline \multicolumn{4}{c}{ Model Summary $^{\mathbf{b}}$} \\
\hline Model & $\mathrm{R}$ & R Square & Adjusted R Square & Std. Error of the Estimate \\
& & & .325 & 2.722 \\
\hline 1 & $.581^{\mathrm{a}}$ & .337 & . & \\
\hline
\end{tabular}

a. Predictors: (Constant), Work Motivation, Work Culture, Professionalism

b. Dependent Variable: Work Quality

Based on the data above, it can be seen that the adjusted $r$ square value is 0.325 . This states that the variables of work culture, professionalism and work motivation together have an influence on work quality by $32.5 \%$.

Based on the data above, it can be seen that directly, the independent variable has a direct influence on the dependent variable. In addition, work motivation variables can also be intervening variables that have a direct influence on the dependent variable. Partially after the first sub-structure, the professionalism variable has a big direct effect on work motivation compared to work culture variables. Whereas in the second sub-structure, work motivation has a greater influence on work quality. The results based on substructure can be seen as follows: 


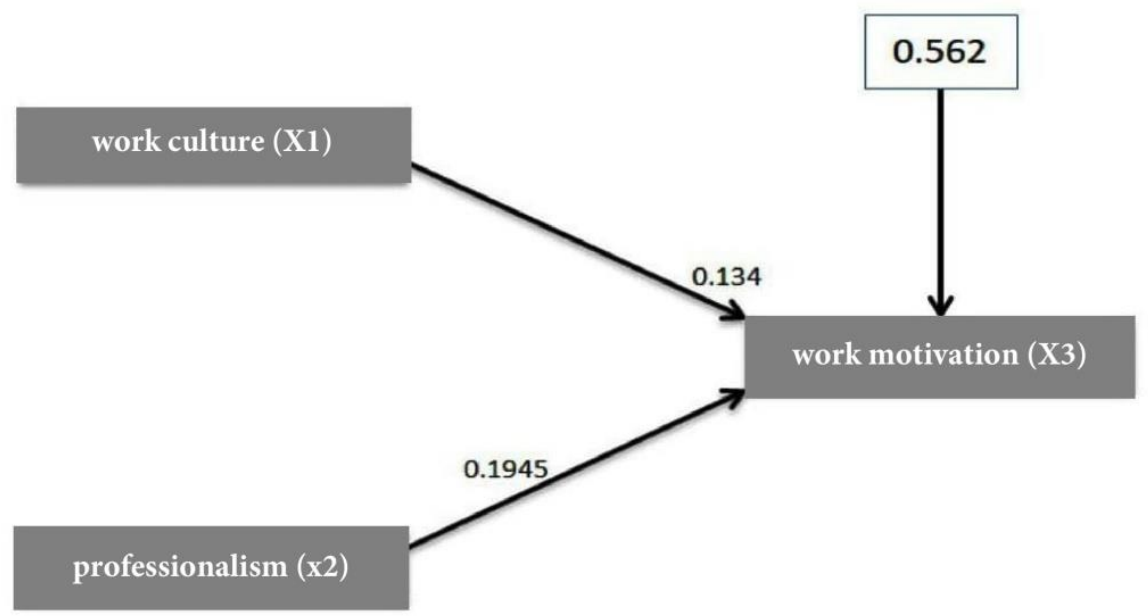

Figure 5

First Sub Structure Research Results

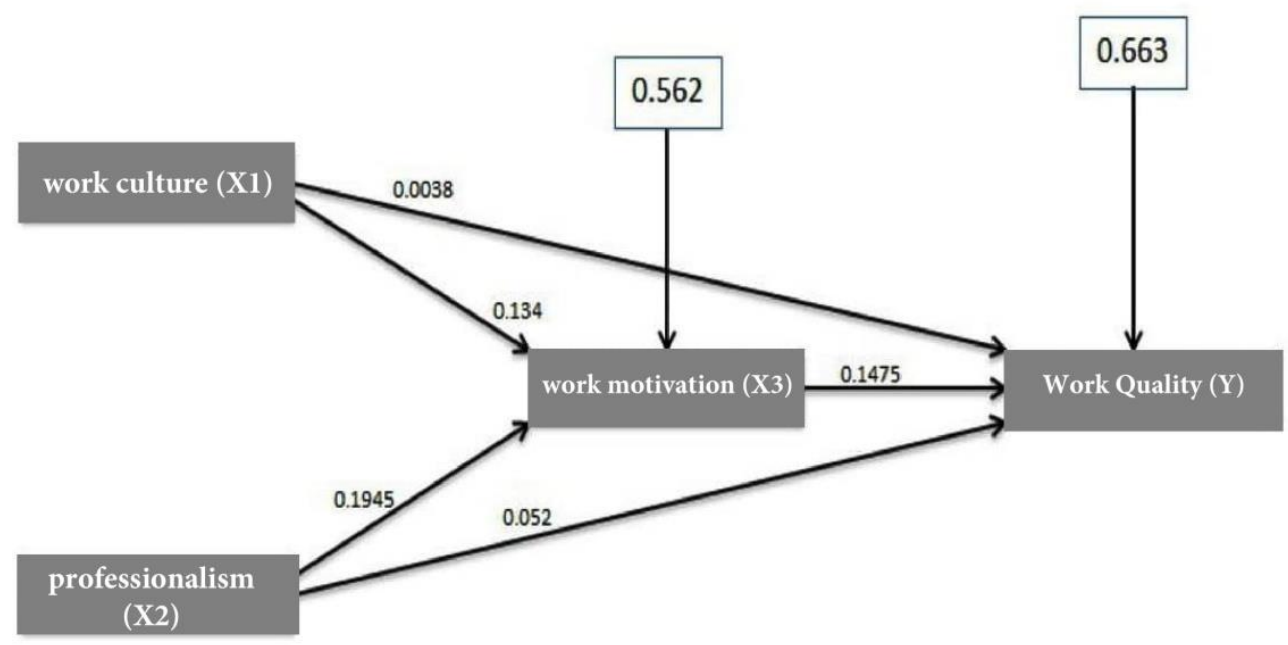

Figure 6

Second Sub Structure Research Results

Based on the results in the table above, the influence of independent variables, both work culture and professionalism has a direct influence on work quality. However, when compared to the indirect effect, the indirect effect has a greater contribution. In other words that work culture will have a strong influence on work quality if employees are also given work motivation. Professionalism will also have a greater effect on work quality if work 
270|Jurnal Ilmiah Ilmu Administrasi Publik: Jurnal Pemikiran dan Penelitian Administrasi Publik

Volume 1o Number 1, January - June 2020. Page 253-274

motivation is used as a moderating variable. The research results described and described above are explained in the following figure:

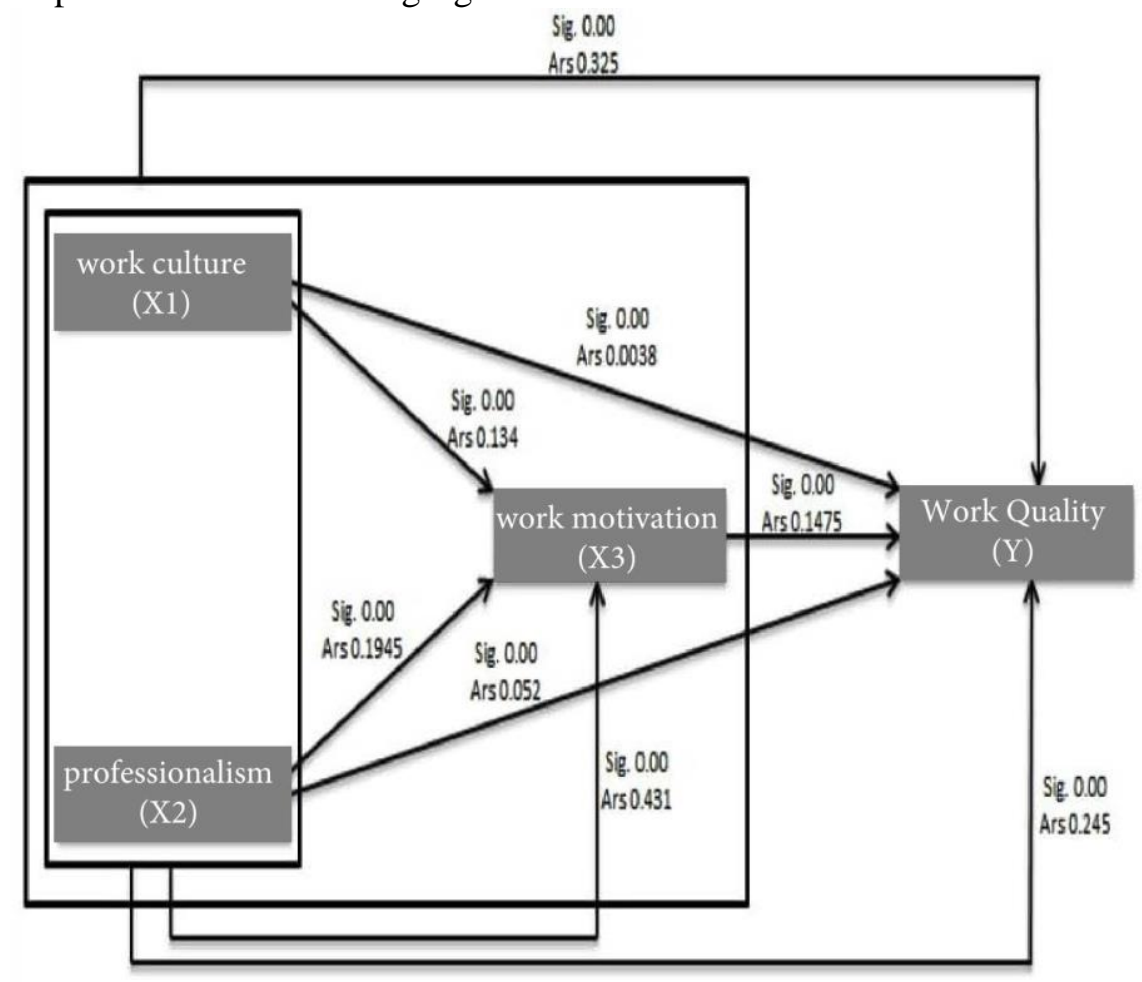

Figure 7

Overall Research Results

Based on the results of research that has been done, it can be stated that the independent variables in this study have an influence on the dependent variable, both directly and indirectly. Work culture that has an influence on work quality is clearly stated by (Ndraha, 2005) which states that work culture is the rationale used to realize quality work, that is work that is effective and efficient and can enhance cooperation among employees in carrying out their duties and function. In addition, the influence of work culture on work quality was also stated by (Frinaldi, 2014) who defines work culture as the foundation for someone's work. This states that work culture is one aspect that has influence in one's work, so that with a good and appropriate work culture in an organization, it will have an impact on the quality of work that is good too. This influence is one form of interaction of values that are understood as a culture in working with employee work environments. In addition, (Moeheriono, 2014) also explained that work culture can increase work productivity. Increased work productivity, is a form of good quality work in an organization.

The results of subsequent studies also stated that the influence of independent variables, professionalism on work quality. The existence of the link is also stated by (Hampton \& Hampton, 2004) which states that professionalism is developed based on 
knowledge and skills, people who have good professionalism, then will provide a clear orientation towards their duties which will later be seen in the quality of one's work, someone who has good professionalism will be able to realize good quality work. In other words, that an employee's knowledge and skills will have an impact on his effective and efficient work. In a country that adopts a democratic system, professionalism is closely related to responsibility. The responsibility in question is the avoidance of mistakes made in the work (Abou Arraj, 2018).

Based on the results of data processing carried out in this study, it was found that the effect of the independent variables on the dependent variable would be even stronger if influenced by the moderating variable, namely work motivation. (Niswaty et al., 2017) states that work motivation is providing the driving force for employees to be able to work effectively and efficiently and with integrity in efforts to achieve organizational goals. Work motivation is also stated as a process to maintain ongoing activities (Pareek, 1974). One important form of influence of work motivation on work quality is the need for employees in the form of incentives as motivation in working.

Based on the results of research that has been done and according to existing theories, work motivation can be a moderating variable. Work culture in an organization can be maintained with work motivation. Work motivation can be used as a moderating variable that can strengthen the influence of work culture on the quality of employee work in an organization. In addition, professionalism also has an influence on work quality. People who have knowledge and skills that are reliable in their work will provide quality services (work) (Daraba et al., 2018).

Based on the results of research that researchers have carried out, the results obtained are that both partially and simultaneously, both directly and indirectly, the independent variables, variables of work culture, professionalism and work motivation have an influence on the dependent variable, namely the quality of work. . Directly and partially, the variable of professionalism has a greater influence on work quality compared to work culture. While work motivation has a greater influence on work quality. In the sobel test that has been carried out to test the feasibility of work motivation as an intervening variable that has a major influence on work quality, the variable can be used as an intervening variable.

The analysis was continued using path analysis. Path analysis as an analysis that measures the magnitude of the indirect effect in research has been carried out in this study. The result is the effect of the independent variable indirectly has a greater percentage than the direct effect of the independent variable on the dependent variable. This can be interpreted that in increasing the influence of work culture and professionalism on the quality of work, work motivation is needed. The purpose of this statement is, in an organization, there is a work culture that affects every job carried out by employees. Therefore, so that the work culture that exists in an organization is able to improve the quality of work of employees in carrying out their duties and functions, then motivation needs to be given to these employees, so that the existing work culture is able to improve the work quality of employees. For example, employees have a work culture to be friendly. The motivation provided in realizing a good quality of work is to give awards to employees who have good performance by always being friendly to the organization's customers (Saggaf et al., 2014; Salam, 2015). 
272 Jurnal Ilmiah Ilmu Administrasi Publik: Jurnal Pemikiran dan Penelitian Administrasi Publik

Volume 1o Number 1, January - June 2020. Page 253-274

The same thing applies to improving the quality of work based on professionalism. Professionalism as a matter relating to one's knowledge and skills has the influence to realize good quality work. In realizing good professionalism, motivation is needed at work, so motivated employees will be motivated to work professionally, so that employees can improve the quality of their work.

\section{CONCLUSION}

Based on this study, it was found that the variables of work culture, professionalism and work motivation have a positive direct relationship to work quality. Then, work culture and professionalism also have an indirect relationship to the quality of work. The indirect relationship is also a positive relationship. The link between these two variables is the work motivation variable. But the results of the study showed that the indirect effect had a stronger effect. This states that work culture and professionalism will make employees have a better work culture if accompanied by good work motivation.

The efforts that can be made by the Padang State University at present to further improve the quality of work of education staff employees are (1) to emphasize the work culture owned by Padang State University as an institutional identity; (2) increase the professionalism of employees by holding some work motivation training, by explaining that with good professionalism, it will bring about good performance ,. Therefore, as a support, awards are given to these employees, both PNS and Non PNS employees. (3) holding periodic motivational training, by socializing the work culture of UNP as a form of realizing the high quality of work of educational staff.

\section{REFERENCES}

Abou Arraj, H. (2018). Professionalism among employees in Lebanon: the Lebanese University. World Journal of Entrepreneurship, Management and Sustainable Development.

Akib, H., \& Ihsan, A. (2017). Bureaucratic Reform in Public Service: A Case Study on the One Stop-Integrated Service. Mediterranean Journal of Social Sciences, 8(2), 253-258.

Clarke, W. (1983). Human resources management. Data Processing. https://doi.org/10.1016/0011-684X(83)90238-1

Creswell, J. W., \& Creswell, J. D. (2017). Research design: Qualitative, quantitative, and mixed methods approaches. Sage publications.

Creswell, J. W., \& Poth, C. N. (2018). Qualitative inquiry Research Design Choosing Among Five Approaches (Vol. 53, Issue 9). SAGE Publications Ltd. https://doi.org/10.1017/CBO9781107415324.004

Daraba, D., Subianto, A. B., \& Salam, R. (2018). An effort to Improve the Quality of Workers at the Makassar city Department of Employment Services. Jurnal Ilmiah Ilmu Administrasi Publik, 8(1), 21-26. 
Farida, U. (2017). Analysis of Empowerment Program that was Implemented in Mamuju Regency East Sulawesi Indonesia. 149(Icest), 19-21.

Frinaldi, A. (2014). Pengaruh Budaya Kerja Pegawai Negeri Sipil Terhadap Pelayanan Publik di Dinas Catatan Sipil dan Kependudukan Kota Payakumbuh. Humanus, 13(2), 180-192.

Hampton, G. M., \& Hampton, D. L. (2004). Relationship of professionalism, rewards, market orientation and job satisfaction among medical professionals: The case of Certified Nurse-Midwives. Journal of Business Research, 57(9), 1042-1053.

Jain, A. (2004). Using the lens of Max Weber's theory of bureaucracy. 37th Annual Hawaii International Conference on System Sciences, 2004. Proceedings of the, 127-136.

Mathwich, N., \& Pavao-Zuckerman, B. (2018). Bureaucratic reforms on the frontier: Zooarchaeological and historical perspectives on the 1767 Jesuit Expulsion in the Pimería Alta. Journal of Anthropological Archaeology, 52, 156-166. https://doi.org/https://doi.org/10.1016/j.jaa.2018.07.002

Meier, K. J., \& Krause, G. A. (2003). The scientific study of bureaucracy: An overview. Politics, Policy, and Organizations: Frontiers in the Scientific Study of Bureaucracy, $1-19$.

Moeheriono, M. (2014). Pengukuran Kinerja Berbasis Kompetensi (Revisi). Jakarta: PT Raja Grafindo Persada.

Nawir, R., Maulana, R., Nuryamin, M., \& Husain, T. (2018). Implementation Program of Poor Rice Copyright. THE INTERNATIONAL CONFERENCE ON SOCIAL SCIENCES AND HUMANITIES 2018.

Ndraha, T. (2005). Kybernologi: sebuah rekonstruksi ilmu pemerintahan. Rineka Cipta.

Niswaty, R., Juniati, F., Darwis, M., Salam, R., \& Arhas, S. H. (2019). The Effectiveness of Leadership Functions Implementation in The Makassar Departement of Manpower. JPBM (Jurnal Pendidikan Bisnis Dan Manajemen), 5(1), 1-10.

Niswaty, R., Rusbiati, S., Jamaluddin, J., \& Salam, R. (2017). The Influence of Teacher's Reinforcement for Students Motivation. International Conference on Education, Science, Art and Technology, 148-152.

Osborne, D., \& Plastrik, P. (1997). Banishing Bureaucracy: The Five Strategies for Reinventing Government. ERIC.

Pareek, U. (1974). A conceptual model of work motivation. Indian Journal of Industrial Relations, 15-31.

Provan, D. J., Dekker, S. W. A., \& Rae, A. J. (2017). Bureaucracy, influence and beliefs: A literature review of the factors shaping the role of a safety professional. Safety Science, 98, 98-112. https://doi.org/https://doi.org/10.1016/j.ssci.2017.06.006

Ripley, R. B., \& Franklin, G. (1968). Policy Implementation and Bureaucracy. The Dorsey 
274|Jurnal Ilmiah Ilmu Administrasi Publik: Jurnal Pemikiran dan Penelitian Administrasi Publik Volume io Number 1, January - June 2020. Page 253-274

Press.

Robbins, S. P. (1994). Teori organisasi: struktur, desain dan aplikasi. Jakarta: Arcan.

Saggaf, S., Salam, R., Kahar, F., \& Akib, H. (2014). Pelayanan Fungsi Administrasi Perkantoran Modern. Jurnal Ad'ministrare, 1(1), 20-27.

Salam, R. (2015). Penerapan Fungsi Administrasi Perkantoran Modern berbasis Daya Saing Organisasi dalam menyongsong MEA 2015. SEMINAR NASIONAL "Revolusi Mental Dan Kemandirian Bangsa Melalui Pendidikan Ilmu-Ilmu Sosial Dalam Menghadapi MEA 2015” Himpunan Sarjana Pendidikan Ilmu-Ilmu Sosial Indonesia, 1, 186-190.

Weber, M. (1946). Bureaucracy. From Max Weber: Essays in Sociology, 196, 232-235.

Weber, M. (1947). Legitimate authority and bureaucracy. The Theory of Social and Economic Organisation, 328-340.

Wihantoro, Y., Lowe, A., Cooper, S., \& Manochin, M. (2015). Bureaucratic reform in postAsian Crisis Indonesia: The Directorate General of Tax. Critical Perspectives on Accounting, 31, 44-63. https://doi.org/https://doi.org/10.1016/j.cpa.2015.04.002

Yusriadi, Sahid, A., Amirullah, I., Azis, A., \& Rachman, A. A. (2019). Bureaucratic Reform to the Human Resouces: A Case Study on the One-Stop Integrated Service. The Journal of Social Sciences Research. 